\title{
Distribution and occurrence of western gall rust in thinned jack pine stands
}

\author{
by S.C. Hills ${ }^{1}$, D.M. Morris ${ }^{1}$ and C. Bowling ${ }^{2}$
}

Jack pine (Pinus banksiana Lamb.) is one of the most important commercial species in northwestern Ontario and is the principal host of one of the most serious stem rusts, western gall rust (WGR) caused by Endocronartium harknessii (J.P. Moore) Y. Hirat. In 1986 a trial was established to determine, in part, effects of precommercial thinning on the distribution and occurrence of WGR in jack pine. A 9 year-old aerially seeded jack pine stand was thinned to square spacings of $1 \mathrm{~m}, 1.5 \mathrm{~m}, 2 \mathrm{~m}, 2.5 \mathrm{~m}, 3 \mathrm{~m}$ and a control. Fifth-year results indicated that a significant quadratic trend $(p=0.014)$ existed between spacing and stem gall infection rate. The incidence of WGR (stem galls) increased as stand density decreased to a maximum at $1.5 \mathrm{~m}$ spacing, and then declined to roughly the infection rate of the control at the lowest density ( $3 \mathrm{~m})$. A significant relationship ( 0.084$)$ between crown class and the rate of branch gall infection rate was also detected. The branch gall infection rate decreased from $6.2 \%$ year $^{-1}$ for dominant trees to $2.8 \%$ year $^{-1}$ for trees categorized as suppressed. Based on these results, pre-commercial thinning operations should target those trees with main stem galls and/or numerous branch galls, regardless of size and crown position, and then focus on the removal of suppressed trees to meet the desired density target. This strategy should not only enhance growth of the remaining trees, but also reduce WGR inoculum levels and reduce future WGRrelated mortality.

Key words: jack pine (Pinus banksiana Lamb.), western gall rust (Endocronartium harknessii (J.P. Moore) Y. Hirat.), pre-commercial thinning, white pine weevil (Pissodes strobi Peck.)
Le pin gris (Pinus banksiana Lamb.) constitue l'une des principales espèces commerciales du nord-ouest de l'Ontario en plus d'être l'hôte de la plus importante des rouilles du tronc, la rouille-tumeur globuleuse (RTG) provoquée par Endocronartium harknessii (J.P. Moore) Y. Hirat. Un essai a été effectué en 1986 afin de déterminer, d'une part, les effets de l'éclaircie précommerciale sur la distribution ainsi que la présence de la RTG dans les peuplements de pin gris. Un peuplement âgé de neuf ans issu d'un ensemencement aérien a été éclairci selon des espacements carrés de $1 \mathrm{~m}$, de $1.5 \mathrm{~m}$, de $2 \mathrm{~m}$, de $2.5 \mathrm{~m}$, et de $3 \mathrm{~m}$ tout en conservant une parcelle-témoin. Les résultats après cinq ans indiquent qu'une relation quadratique significative $(P=0.014)$ existe entre l'espacement et le taux d'infection par la rouille. Le taux d'infection de la RTG (tumeurs de tige) a augmenté alors que la densité du peuplement diminuait passant d'une valeur maximale à un espacement de $1.5 \mathrm{~m}$, pour par la suite diminuer pour atteindre à peu près le taux d'infection du témoin au niveau de la densité la plus faible ( $3 \mathrm{~m})$. Une relation significative $(0.084)$ entre la classe de cime et le niveau d'infection par la tumeur sur les branches a également été détectée. Le niveau d'infection par la tumeur sur les branches a diminué de $6.2 \%$ par an pour les arbres dominants et de $2.8 \%$ par an pour les arbres de la classe dominée. En fonction de ces résultats, les opérations d'éclaircie précommerciale devraient viser les arbres dont le tronc principal et/ou plusieurs branches sont infectées par la rouille, sans égard à la hauteur et à la position de la cime, et puis s'attarder sur l'élimination des arbres dominés afin de rencontrer l'objectif visé de densité. Cette stratégie devrait non seulement améliorer la croissance des arbres résiduels, mais également réduire le niveau d'inoculum de la RTG ainsi que la mortalité reliée à la RTG dans l'avenir.

Mots clés: Pin gris (Pinus banksiana Lamb.), rouille-tumeur globuleuse (Endocronartium harknessii (J.P. Moore) Y. Hirat), éclaircie précommerciale, charançon du pin blanc (Pissodes strobi (Peck.)

\section{Introduction}

Jack pine (Pinus banksiana Lamb.) is a commercially important softwood species accounting for $12.8 \%$ of the total growing stock volume in Ontario (OMNR 1986). In 1989, over 6 million $\mathrm{m}^{3}$ of jack pine worth almost half a billion dollars were harvested in Ontario, a value second only to spruce (OMNR 1990). Jack pine is used for pulp, lumber, railroad ties and poles. In the northwestern part of the province, seeding of jack pine is a viable regeneration technique and aerial seeding is becoming the predominant regeneration treatment in the area. This treatment is relatively inexpensive compared to plantation-related

\footnotetext{
${ }^{1}$ Ontario Ministry of Natural Resources, Ontario Forest Research Institute, Centre for Northern Forest Ecosystem Research, c/o Lakehead University, 955 Oliver Road, Thunder Bay, Ontario, Canada P7B 5E1.

${ }^{2}$ Ontario Ministry of Natural Resources, Northwest Region Science and Technology, 25th Side Road, R.R. \#1, Thunder Bay, Ontario, Canada P7C 4T9.
}

costs of growing, planting and tending. In 1988, more than 10,000 ha were aerially seeded representing almost $60 \%$ of the regenerated area in the Northwest Region of Ontario (White and Waldram 1991). One of the most aggressive pre-commercial thinning programs takes place in the Dryden District of Ontario. A pre-commercial thinning program was initiated in 1985 within the District and since then approximately 6,600 ha have been thinned. Jack pine regeneration in the District is sufficient to maintain a pre-commercial thinning program of 1,500 to 1,800 ha year $^{-1}$ (Pletch 1991).

There are many diseases of jack pine, but stem rusts are among the most destructive and dangerous (Boyce 1957). One of the most serious stem rusts of jack pine is western gall rust (WGR) caused by Endocronartium harknessii (J.P. Moore) Y. Hirat. which produces perennial woody galls on many hard pines. WGR is caused by an autoecious stem rust that requires only one host (a hard pine) to complete its life cycle. This makes WGR especially dangerous to pine plantations or aerially seeded areas where 
stands are often comprised of few other tree species. WGR branch and stem galls result in growth loss, poor tree form, stem breakage, reductions in wood quality and ultimately affect product end use (Gross 1983). Van der Kamp (1981) studied several diseases including WGR in juvenile spaced stands, plantations and well-spaced young natural stands of lodgepole pine in the Interior of British Columbia. Trees in this study were $1-10 \mathrm{~m}$ in height and ranged in age from 5 to 44 years. Van der Kamp estimated that, for the stands studied, the total loss to gall rust would be about $5 \%$ of the stand volume at rotation age.

Much research has been conducted to understand the life history and development of WGR. This work has focused on a variety of different areas including nursery and plantation infections (Powell and Hiratsuka 1973; Gross and Syme 1980; Hiratsuka 1981; Hiratsuka et al. 1988; Juzwik and Chong 1990); geographical and host distribution (Dietrich et al. 1985); host resistance and susceptibility (Martinsson 1980; Burnes et al. 1988; van der Kamp 1988b; Yanchuk et al. 1988; Blenis et al. 1993); disease development, infection mechanisms and inoculation techniques (Allen and Hiratsuka 1985; Blenis and Hiratsuka 1986; Allen et al. 1988; Allen et al. 1990); taxonomy, management and control (Hiratsuka 1991a; Hiratsuka 1991b). To a lesser extent, the relationship between the disease and stand density has also been studied (Bella 1985; van der Kamp and Spence 1987; Blenis and Bernier 1986; Bella and Navratil 1988; Doidge et al. 1991; Blenis and Duncan 1992).

In Ontario, however, the majority of effort has been via Forestry Canada's infection level monitoring program conducted by the Forest Insect and Disease Survey Unit (FIDS). Relatively little published work is available on WGR in Ontario jack pine stands (Gross and Syme 1980; Gross 1983; Juzwik and Chong 1990), yet a substantial percentage of Ontario's forests are being planted, seeded or naturally regenerated to jack pine. Since areas of jack pine regeneration appear to be susceptible to WGR, a considerable amount of area may be damaged by WGR and secondary wood decay and staining organisms. Some have suggested that intensive management practices such as thinning, spacing and fertilizing may favour WGR incidence damage and mortality (Hiratsuka et al. 1987). More jack pine areas of northwestern Ontario will probably undergo pre-commercial thinning to improve growth, but this may be predisposing these stands to elevated infection rates of WGR. Therefore the objective of this study was to determine if pre-commercial thinning has an effect on the distribution and occurrence of WGR in young jack pine stands.

\section{Methods and Materials}

In 1975 , a mature jack pine area located about $30 \mathrm{~km}$ northwest of Dryden, Ontario was conventionally harvested. The soil was a medium-texture sand (FEC Soil Type S2, as described by Sims et al. (1989)). The 38 ha area was scarified using barrels and chains in 1976 and then aerially seeded to jack pine in the winter of 1977. In the fall of 1986, a thinning trial was set up to determine short-term responses of jack pine to varying levels of thinning. One objective of the trial was to quantify the growth and form response of aerially seeded juvenile jack pine in relation to pre-commercial thinning regimes. The nine-year-old jack pine stand was thinned to square spacings of $1 \mathrm{~m}\left(10,000\right.$ stems ha $\left.^{-1}\right), 1.5 \mathrm{~m}$ (4444 stems ha $\left.{ }^{-1}\right), 2 \mathrm{~m}$ (2500 stems ha $\left.{ }^{-1}\right), 2.5 \mathrm{~m}$ (1600 stems ha- $\left.{ }^{-1}\right)$, and $3 \mathrm{~m}$ (1111 stems ha $\left.{ }^{-1}\right)$. Control plots (approximately 21,250 stems ha ${ }^{-1}$ ) were left for comparison. These five thinning regimes and controls were replicated four times in a randomized complete block design (Fig. 1). Each of the 24 plots was 0.06 ha $(24 \mathrm{~m} \times 24 \mathrm{~m})$. Unwanted stems were removed with brush saws. Selection of leave-trees was based solely on spacing, using a grid coordinate system, and not on tree condition and vigour as in most pre-commercial thinning operations. After thinning, 36 trees plot $^{-1}$ were randomly selected, using grid coordinates, and permanently tagged for remeasurement. Again, tree size, health, and vigour were not used in the selection process.

Data collected in 1986 included: total tree height, DBH, diameter at 0.3 of the height, and tree condition (presence of stem galls, branch galls, white pine weevil, multiple leaders). In the fall of 1991, as many sample trees as possible were relocated and reassessed for insect and disease damage. The assessment was evaluated qualitatively, using multi-state variables, as follows:

a. Western Gall Rust (stem):

1 - no galls

2 - minor galls $(<70 \%$ stem encirclement)

3 - severe galls ( $>70 \%$ stem encirclement)

b. Western Gall Rust (branch):

1 - no galls

$2-1$ to 10 galls

$3-11$ to 20 galls

$4-21+$ galls

c. Other Stem Damage:

1 - no other damage

2 - white pine weevil

3 - borer

4 - other

5 - weevil and borer

6 - weevil and other

7 - borer and other

d. Number of Leaders:

1 - one dominant leader

2 - multiple leaders (two or more)

WGR stem was subdivided as minor or severe based on the premise that a severe stem gall is one or more galls that encircle greater than $70 \%$ of the diameter of the stem. Gross (unpublished results) indicated that trees with stem galls classified as severe rarely survive. WGR branch was subdivided based on number of galls on branches in the crown.

Using the 1986 and 1991 WGR assessment data, rates of infection for WGR were calculated for each treatment plot and summarized by both spacing (Table 1) and crown class (Table 2). The following equation was used to obtain these rates of infection:

$$
I R=\left[\left(N_{86}-N_{91}\right) /\left(T \times N_{86}\right)\right] \times 100
$$

where $I R=$ infection rate year ${ }^{-1}$ as a percentage of healthy stems, $N_{86}$ and $N_{91}=$ number of unaffected stems for treatment plots in 1986 and 1991 , respectively, $T=$ number of years between assessments.

Since spacing took precedence over tree size when selecting "leave" trees, the proportion of individuals in the various crown classes was similar across the spacing levels. As a result, the experiment was analyzed, using PROC ANOVA with- 


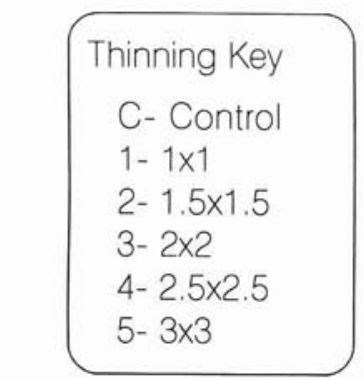

Mature Jack Pine

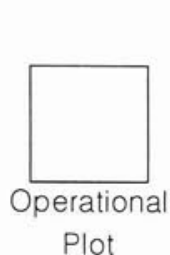

Block 2 Block 1

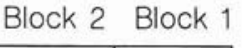

$$
\text { Plot }
$$

\section{Block 3}

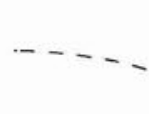

$-1$

Alder Swale

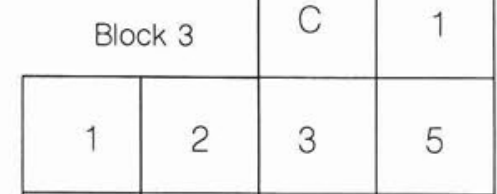

\begin{tabular}{l|l|l|l|}
\hline 3 & $C$ & 4 & 4 \\
\hline
\end{tabular}

3

\begin{tabular}{|l|l|}
\hline 1 & 2 \\
\hline 2 & $C$ \\
\hline
\end{tabular}

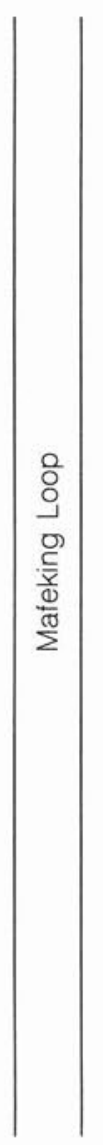

Block 4
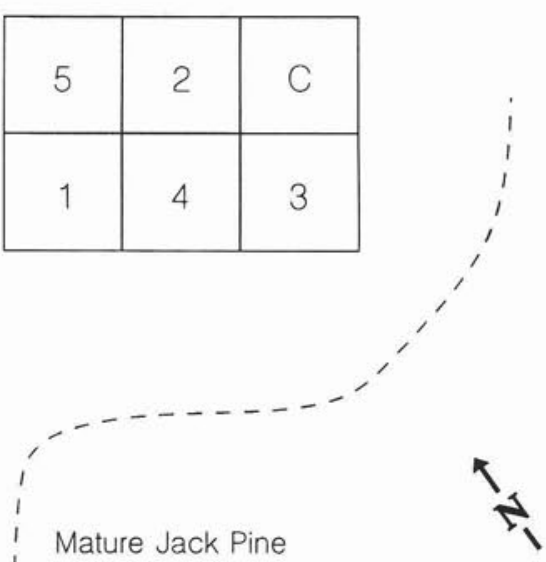

Mature Jack Pine

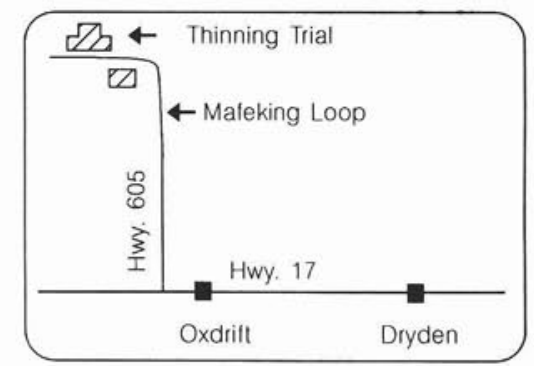

Figure 1. Sketch map detailing the experimental layout of thinning trial.

in the SAS statistical software package (SAS Institute, Inc. 1988), as a factorial with both density and crown class as main effects: The spacing treatments represent a continuum of quantitative treatments, and therefore the relationship between spacing and rate of WGR infection was examined using trend analysis, Mize and Schultz (1985). For crown class, where trees are grouped into categories of similar growth habit, StudentNewman-Keuls (S-N-K) multiple range test was applied to evaluate differences between treatment means.

\section{Results and Discussion}

\section{Weevil Incidence and Other Damage}

Within this trial, other damage was attributable to White Pine Weevil (Pissodes strobi Peck.) and multiple leaders for both the 1986 and 1991 measurement years (Tables 1 and 2). Sajan and Brodersen (1991) reported, for northwestern Ontario, that on average $3.7 \%$ of leaders on jack pine (1-5 $\mathrm{m}$ in height) were damaged by weevil. Other districts have recorded attacks as high as $11 \%$. Our results for 1991 indicated $6 \%$ of the stems within the stand had current weevil damage. As a stand average, this percentage is lower than the $15 \%$ reported in the 1986 assessment. Although differences were noted among spacing treatments, ranging from $0 \%$ in the $1 \mathrm{~m}$ spacing to $11 \%$ in the $3 \mathrm{~m}$ spacing (Table 1), no significant relationship was detected. As with spacing, no apparent relationship existed between crown class and weevil incidence (Table 2). The decrease in weevil incidence was probably more closely related to stand conditions and tree physiology (Wallace and Sullivan 1985), but Lavalleé (1992) suggests that these phenomenon may be more evident in naturally regenerated sites than in plantations where environmental conditions are less diverse.

The decrease in weevil incidence is in contrast to an increase in multiple leaders (Table 1: $1986-4 \% ; 1991-24 \%$ ). As was the case for weevil incidence, no significant relationship occurred between multiple leadering and spacing or crown class. The detected increased occurrence of multiple leadering could simply be an expression of the high rate of weevil damage up to and including 1986.

\section{WGR Incidence and Damage}

Forestry Canada's 1990 insect and disease survey results (Sajan and Brodersen 1991) for the Northwestern Region indicated that $20 \%$ of all sampled trees $(2-4 \mathrm{~m}$ tall) were affected by WGR stem galls, and that roughly one-third of those were severely affected. For trees 6-8 $\mathrm{m}$ in height, infection rates were 5-10\% with roughly $5 \%$ severely affected. Our results indicated, of the trees measured in 1991, almost $19 \%$ were infected with WGR stem galls and $33.8 \%$ with branch galls. However, a portion of these trees ( $7 \%$ - stem galls; $9.5 \%$ - branch galls) were infected prior to 1986. Therefore to obtain more realistic estimates of WGR infection rates, one needs to determine the number of new infections which occurred during the five-year period of the study. 
Table 1. Incidence of damage, by spacing, for jack pine trees five years after thinning.

\begin{tabular}{|c|c|c|c|c|c|c|c|c|c|c|}
\hline \multirow{3}{*}{$\begin{array}{l}\text { Spacing } \\
\text { (m) }\end{array}$} & \multirow{2}{*}{\multicolumn{2}{|c|}{$n$}} & \multirow{2}{*}{\multicolumn{2}{|c|}{$\begin{array}{c}\text { Multiple } \\
\text { leaders }\end{array}$}} & \multirow{2}{*}{\multicolumn{2}{|c|}{ Weevil }} & \multirow{2}{*}{\multicolumn{2}{|c|}{$\begin{array}{c}\text { Pre-86 WGR } \\
\text { Infection level }\end{array}$}} & \multicolumn{2}{|c|}{ Rate of WGR infection } \\
\hline & & & & & & & & & \multirow{2}{*}{$\frac{\text { Stem }}{\left(\% \mathrm{yr}^{-1}\right)}$} & \multirow{2}{*}{$\frac{\text { Branch }}{\left(\% \mathrm{yr}^{-1}\right)}$} \\
\hline & 86 & 91 & 86 & 91 & 86 & 91 & Stem & Branch & & \\
\hline & & & & & & & & 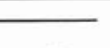 & & \\
\hline $\mathrm{C}$ & 140 & 131 & 1 & 18 & 18 & 4 & 5.0 & 8.4 & 1.3 & 4.3 \\
\hline 1 & 139 & 130 & 7 & 15 & 9 & 0 & 5.5 & 6.9 & 3.0 & 4.6 \\
\hline 1.5 & 122 & 108 & 3 & 28 & 17 & 6 & 4.2 & 14.7 & 3.7 & 4.3 \\
\hline 2 & 128 & 110 & 6 & 33 & 22 & 6 & 9.0 & 16.9 & 3.3 & 5.2 \\
\hline 2.5 & 141 & 128 & 2 & 22 & 20 & 6 & 8.3 & 6.3 & 2.6 & 5.0 \\
\hline 3 & 135 & 112 & 5 & 26 & 16 & 11 & 10.0 & 3.7 & 1.1 & 6.4 \\
\hline Stand Totals & 864 & 719 & 4 & 24 & 15 & 6 & 7.0 & 9.5 & 2.5 & 5.5 \\
\hline
\end{tabular}

${ }^{1}$ Treatment densities $\left(\right.$ stems ha $\left.^{-1}\right)$ were calculated using average intertree distances obtained in $1991(\mathrm{c}-20,630 ; 1 \mathrm{~m}-7,588 ; 1.5 \mathrm{~m}-3,519 ; 2 \mathrm{~m}-2,112 ;$ $2.5 \mathrm{~m}-1,292 ; 3 \mathrm{~m}-1,004)$.

Table 2. Incidence of damage, by crown class, for jack pine trees five years after thinning.

\begin{tabular}{|c|c|c|c|c|c|c|c|c|c|}
\hline \multirow{3}{*}{$\begin{array}{l}\text { Crown } \\
\text { Class } \\
\end{array}$} & \multirow[b]{3}{*}{$\boldsymbol{n}$} & \multirow{2}{*}{\multicolumn{2}{|c|}{$\begin{array}{c}\text { Multiple } \\
\text { leaders }\end{array}$}} & \multirow{2}{*}{\multicolumn{2}{|c|}{ Weevil }} & \multirow{2}{*}{\multicolumn{2}{|c|}{$\begin{array}{c}\text { Pre-86 WGR } \\
\text { Infection level }\end{array}$}} & \multicolumn{2}{|c|}{ Rate of WGR infection } \\
\hline & & & & & & & & \multirow{2}{*}{$\frac{\text { Stem }}{\left(\% \mathrm{yr}^{-1}\right)}$} & \multirow{2}{*}{$\frac{\text { Branch }}{\left(\% \mathrm{yr}^{-1}\right)}$} \\
\hline & & 86 & 91 & 86 & 91 & stem & branch & & \\
\hline & & & & & $-(\%)$ & & 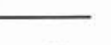 & & \\
\hline Dominant & 270 & 1.9 & 8.9 & 9.6 & 1.9 & 5.8 & 6.9 & 1.8 & 6.2 \\
\hline CoDom. & 239 & 2.5 & 13.0 & 9.6 & 3.8 & 6.7 & 8.3 & 2.6 & 5.3 \\
\hline Inter. & 143 & 4.2 & 16.1 & 11.9 & 2.8 & 7.1 & 7.1 & 2.8 & 4.2 \\
\hline Supp. & 66 & 3.0 & 50.0 & 25.8 & 12.1 & 6.6 & 7.2 & 2.3 & 2.8 \\
\hline
\end{tabular}

The stem gall infection rate was $2.5 \%$ year $^{-1}$ with $51 \%$ of these new infections (1.5\% of total stems) being classified as severe. A higher branch gall infection rate of $5.5 \%$ year $^{-1}$ was detected, but only $17 \%$ of these infected individuals $(1.0 \%$ of total stems) were classified as having severe branch galls (greater than 11 galls tree $^{-1}$ ). Gross and Syme (1980) report a gradient from west to east in WGR infection levels. Recently, in northwestern Ontario, infection rates of $6.7 \%$ to $17.2 \%$ were reported with main stem galls found more frequently than branch galls (Juzwik and Chong 1990). In Minnesota, Dietrich et al. (1985) reported that $46 \%$ of jack pine stands they surveyed were infected by WGR. They also found marked differences in the range of WGR which was contained mainly to the northeastern part of the state, which borders Ontario.

\section{Relationship between Stand Density and WGR Infection}

Van der Kamp and Spence (1987) suggested two ways in which spacing can affect rust incidence: 1) the effect of selective removal can alter rust incidence and 2) the new stand structure created by spacing may alter microclimatic conditions, crown structure and inoculum levels, which may change the rate of infection. Results from past research seem to suggest that WGR incidence increases with decreasing stand density. For example, Bella (1985) found that WGR incidence in thinned stands was $30 \%$ compared to $18 \%$ in unthinned stands. Although van der Kamp (1988a) found that WGR infection did not vary significantly over the range of natural stand densities of lodgepole pine, Doidge et al. (1991) reported WGR infection rates of $14 \%, 5.5 \%$, and $4.5 \%$ for plantations, spaced stands and natural stands of lodgepole pine 10-20 years old. Many of the previous studies of WGR incidence in thinned or spaced stands were conducted in pre-commercially thinned plantations, where the healthiest and most vigorous trees were preferentially retained. Therefore, some bias occurs in disease surveys as a result of this selective removal. In the current study, however, crop tree selection was based solely on spacing, irrespective of tree condition, thereby allowing an assessment of the influence stand density and crown structure had on the rate of WGR infection.

The results from the current study (Table 1) indicate that the rate of WGR stem gall infection increased from the control (1.3\% per year) to the $1.5 \mathrm{~m}$ spacing ( $3.7 \%$ per year) and then declined to $1.1 \%$ per year in the $3 \mathrm{~m}$ spacing. Results from the analysis of variance (Table 3 ), confirmed that a significant quadratic trend $(p=0.014)$ with a non-significant lack of fit $(p=0.268)$ existed between spacing and stem gall infection rate. This trend is illustrated (Fig. 2). Although the rate of branch gall infection varied from $4.3 \%$ year $^{-1}$ (control and $1.5 \mathrm{~m}$ ) to $6.4 \%$ year $^{-1}(3 \mathrm{~m})$, no significant trend with spacing was identified from the ANOVA (Table 3).

\section{Relationship between Crown Classification and WGR Infection}

The rates of WGR infections by each crown class were summarized (Table 2). No significant relationship between crown class and rate of stem gall infection was found (Table 3: $p=0.568$ ). The ANOVA did, however, identify a significant relationship $(p=0.084)$ between crown class and the rate of branch gall infection. As depicted in the S-N-K results (Table 3), the rate of branch gall infection decreased from $6.2 \%$ year $^{-1}$ for trees in the dominant category, which have a greater amount of branch tissue available for infection, to $2.8 \%$ year $^{-1}$ for trees categorized as suppressed. 
Table 3. Summary of ANOVA results for WGR stem and branch infection rates 5 years after thinning

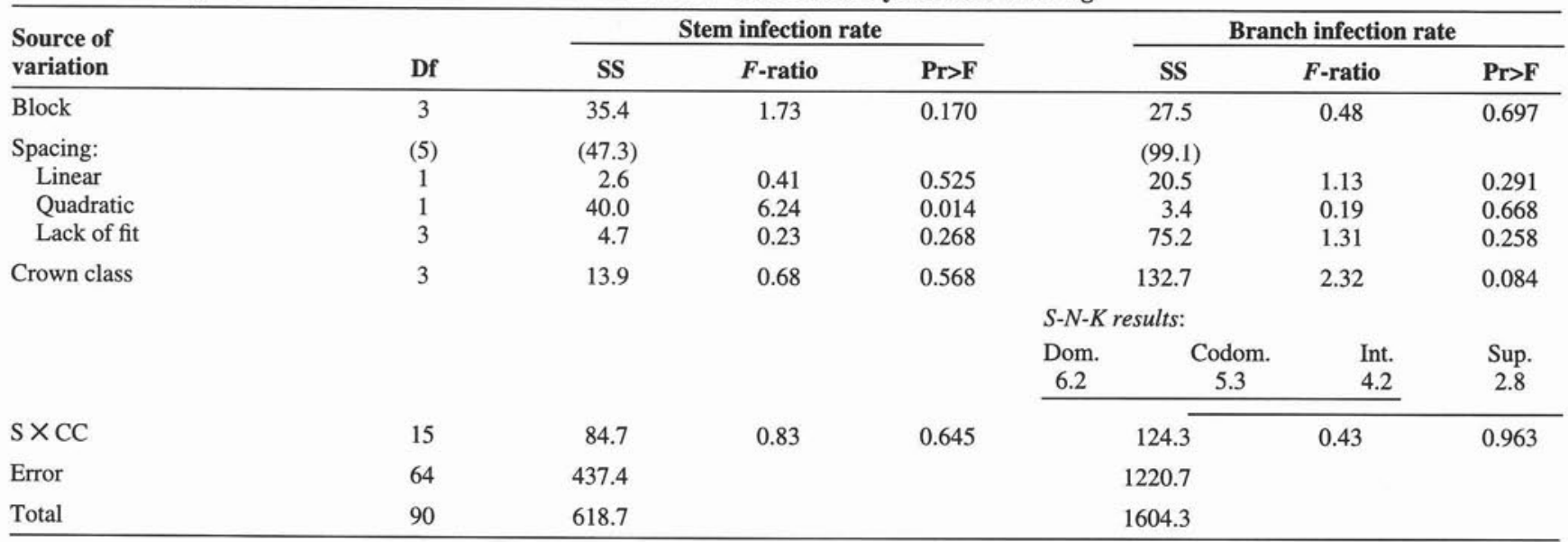

\section{Management Implications}

The incidence of WGR (stem galls) increased as the stand density decreased to a maximum at the $1.5 \mathrm{~m}$ spacing. At the lowest density ( $3 \mathrm{~m}$ spacing) the infection rate declined to roughly the infection rate of the control (Fig. 2). This trend is of particular interest when managing stand density. Currently, prescriptions for operational pre-commercial thinning in jack pine have a density target of 2,500 stems ha $^{-1}$ ( $2 \mathrm{~m}$ spacing). Based on the results of the current study, these operationally thinned stands may experience above-normal WGR stem infection rates. Since it is rare for a tree infected with a stem gall to survive, higher mortality rates and a further reduction in stand density could also be anticipated in this study area. The relationship depicted (Fig. 2) might suggest a biological limitation to the rust itself. For example, it may be hypothesized that the microclimatic environment the spores require for successful establishment does not exist in the wider spacings. WGR spore survival decreases with increasing temperature and relative humidity, with the optimum temperature being $18-20^{\circ} \mathrm{C}$ and a relative humidity between $90-95 \%$ (Chang and Blenis 1986). Unfortunately, no research to date has characterized the microclimates which develop under different canopy densities.

Currently, operational thinning utilizes a "thinning-from-below" strategy removing primarily the smallest trees. However, the occurrence of WGR (stem galls) is not related to crown class (Table 3) and appears to be acting as an inefficient natural thinning agent. It is inefficient because trees of all sizes are killed and because it takes an extended (prolonged) period for the tree to die (van der Kamp 1988a). By utilizing existing knowledge of WGR, one could design a more effective approach to operational thinning. For example, stands chosen to be pre-commercially thinned should be surveyed for the presence of WGR. If the rust is present, even in moderate numbers, then the stocking targets should be increased to allow for future mortality and damage. In addition, thinning operations should target those trees with main stem galls and/or numerous branch galls, irregardless of size and crown position, and then focus on the removal of suppressed trees to meet the desired density target. This strategy should not only enhance growth of the remaining trees, but also reduce inoculum levels and reduce future WGR-related mortality. However, the effects in inocu-

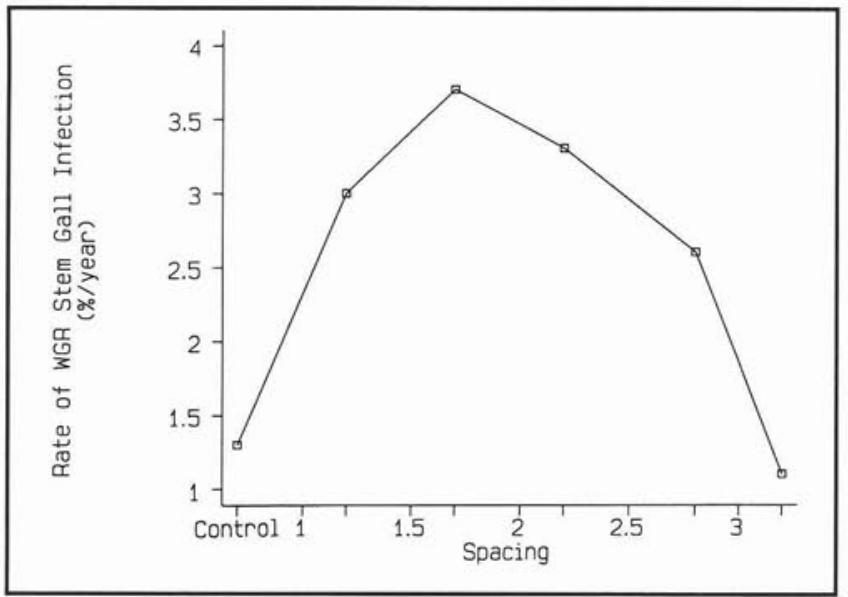

Figure 2. Depiction of quadratic relationship between the rate of WGR (stem gall) infection and spacing 5 years after thinning. Calculated spacings, based on average intertree distances, were used as $\mathrm{X}$ coordinates.

lum load on our small plots may not be similar to those on large areas. The relationship needs to be verified.

Since thinning and spacing juvenile jack pine is an important silvicultural tool, it is essential that effects of WGR over various densities be further evaluated and developed, integrating these results into site classification systems. Integrating WGR hazard zones into site classification will help ensure that money spent in tending and planting is spent on the most productive and less WGR sensitive sites. Any classification system, however, needs to not only account for this spatial component (e.g. high risk sites), but also needs to consider a temporal component (e.g. wave years).

Several research organizations across the U.S. and Canada are now routinely testing plus-tree and family selections for relative resistance to WGR and other destructive stem rusts (Hiratsuka et al. 1991). Reports by several authors in a recent "Rusts of Pine Proceedings" (Hiratsuka et al. 1991), indicate that substantial genetic variation exists in resistance of hard pines to WGR. This suggests that gains can be made by the artificial 
selection of the most resistant families, resulting in pines with a narrower range of susceptibility. Some of these same programs are developing a WGR site hazard rating system to integrate into their respective site classification systems. Research in Ontario needs to concentrate on developing and incorporating hazard zones into site classification systems, identifying the mechanisms of resistance and susceptibility of jack pine to WGR, and screening and testing of jack pine resistance by seedling inoculations.

\section{Acknowledgements}

The authors would like to recognize and thank Bob White, former Northwestern Region Silviculture Forester, Kenora, for his foresight in initiating this field trial and Dr. Keith McClain, former Senior Scientist of the Northern Forest Research Unit, Thunder Bay, for his assistance in establishing the trial in 1986.

The authors greatly appreciated all of the dedicated assistance provided by Glen Niznowski (Northwest Region Science and Technology), Pat Corbett (Area Supervisor), Dryden Crown Forest), and other staff of the OMNR Dryden District in establishing, maintaining, and measuring the trial. In addition, the authors greatly appreciated the discussion, comments, and unpublished data provided by Dr. Henry Gross (Forestry Canada, Ontario Region) in dealing with the subject, as well as the constructive comments and suggestions provided by two anonymous reviewers.

\section{References}

Allen, E.A. and Y. Hiratsuka. 1985. Artificial inoculation of young seedlings of lodgepole pine with Endocronartium harknessii. Can. J. Bot. 63: 1168-1170.

Allen, E.A., P.V. Blenis and Y. Hiratsuka. 1988. Axenic culture of Endocronartium harknessii. Mycologia 80: 120-123.

Allen, E.A., P.V. Blenis and Y. Hiratsuka. 1990. Early symptom development in lodgepole pine seedlings infected with Endocronartium harknessii. Can. J. Bot. 68: 270-277.

Bella, I.E. 1985. Pest damage incidence in natural and thinned lodgepole pine in Alberta. For. Chron. 61: 233-238.

Bella, I.E. and S. Navratil. 1988. Western gall rust dynamics in young lodgepole pine stands in west-central Alberta. Can. J. For. Res. 18: 1437-1442.

Blenis, P.V. and P.Y. Bernier. 1986. Incidence of western gall rust infection of lodgepole pine regeneration in different-sized forest openings. Can. J. For. Res. 16: 1327-1329.

Blenis, P.V. and I. Duncan. 1992. Endocronartium harknessii in thinned Pinus contorta var. latifolia stands. Phytopathology 82: 1117.

Blenis, P.V., H.D. Pinnell and S.E.T. John. 1993. Stand, family, and rust-source effects on four attributes of lodgepole pine resistance to western gall rust. Can. J. For. Res. 23: 144-150.

Boyce, J.S. 1957. The fungus causing western gall rust and Woodgate rust of pines. For. Sci. 3: 225-234.

Burnes, T.A., R.A. Blanchette, C.G. Wang, and D.W. French. 1988. Screening jack pine seedlings for resistance to Endocronartium harknessii. Plant Disease 72: 614-616.

Chang, K. F. and P.V. Blenis. 1986. Release and survival of peridermioid teliospores of Endocronartium harknessii produced on lodgepole pine. Phytopathology 76: 1058.

Dietrich, R.A., R.A. Blanchette, C.F. Croghan and S.O. Phillips. 1985. The distribution of Endocronartium harknessii and Cronartium quercuum on jack pine in Minnesota. Can. J. For. Res. 15: 1045-1048. Doidge, D., J. Richmond and J. Muir. 1991. Incidence of western gall rust and blister rust on young lodgepole pine in the Cariboo Forest Region. Can. Plant Dis. Surv. 71: 134-135.

Gross, H.L. 1983. Negligible cull and growth loss of jack pine associated with globose gall rust. For. Chron. 59: 308-311.

Gross, H.L. and P.D. Syme. 1980. Results of a special survey of high value jack pine stands in northern Ontario. C.F.S. G.L.F.C. FIDS Special Survey \#3.

Hiratsuka, Y.1981. Western gall rust infection of nursery origin on jack pine in Manitoba. C.F.S. N.F.R.C. For. Man. Note No. 5.

Hiratsuka, Y. 1991a. Nuclear cycle, taxonomy and nomenclature of western gall rust. pp 92-101 In Y. Hiratsuka, J.K. Samoil, P.V. Blenis, P.E. Crane and B.L. Laishley (eds.) Rusts of Pine. Proc. 3rd IUFRO Rusts of Pine Working Party Conf., Sept 18-22, 1989, Banff, Alberta, For. Can. Northwestern Region. Inf Rep NOR-X-317.

Hiratsuka, Y. 1991b. A new strategy for the biological control of pine stem rusts. pp 371-377 In Y. Hiratsuka, J.K. Samoil, P.V. Blenis, P.E. Crane and B.L. Laishley (eds.) Rusts of Pine. Proc. 3rd IUFRO Rusts of Pine Working Part Conf., Sept 18-22, 1989, Banff, Alberta, For. Can. Northwestern Region. Inf Rep NOR-X-317.

Hiratsuka, Y., P.V. Blenis and K.F. Chang. 1987. The role of biotic and climatic factors in the epidemiology of western gall rust. Agric. For. Bull. 10: 11-13.

Hiratsuka, Y., J.M. Powell and G.A. Van Sickle. 1988. Impact of pine stem rusts of hard pines in Alberta and the Northwest Territories. Can. For. Serv. North. For. Cent. Edmonton. Inf. Rep. NOR-X-299. Hiratsuka, Y., J. K. Samoil, P.V. Blenis, P.E. Crane and B.L. Laishley. 1991. Rusts of Pine. Proc. 3rd IUFRO Rusts of Pine Working Party Conf., Sept. 18-22, 1989, Banff, Alberta, For. Can. Northwestern Region. Inf Rep NOR-X-317

Juzwik, J. and N. Chong. 1990. Pine-pine gall rust on young jack pine in northwestern Ontario. Northern Journal of Applied Forestry 7: 133-136.

Lavalleé, A. 1992. Observations on the evolution of damage by Pissodes strobi Peck and characterization of young white pine plantations affected by this weevil. For. Can., Quebec Region. Inf. Rep LAU-X-98E.

Martisson, O. 1980. Stem rusts in lodgepole pine provenance trials. Silvae Genetica 29: 23-26.

Mize, C.W. and R.C. Schultz. 1985. Comparing treatment means correctly and appropriately. Can. J. For. Res. 15: 1142-1148.

Ontario Ministry of Natural Resources. 1986. The forest resources of Ontario. Queen's Printer for Ontario, Toronto.

Ontario Ministry of Natural Resources. 1990. Statistics 19881989. Queen's Printer for Ontario, Toronto.

Pletch, M. 1991. Experiences with juvenile spacing of jack pine in Ontario. pp 126-127 In V.F. Haavisto, C.R. Smith and C. Mason (eds.) Space to grow: spacing and thinning in northern Ontario. 1991. Forestry Canada, Ontario Region Joint Report 15.

Powell, J.M. and Y. Hiratsuka. 1973. Serious damage caused by stalactiform blister rust and western gall rust to a lodgepole pine plantation in central Alberta. Can. Plant Dis. Surv. 53: 67-71.

Sajan, R.J. and H. Broderson. 1991. Results of the forest insect and disease surveys in the north western region of Ontario, 1990. Forestry Canada Ontario Region Misc. Rep. No. 101.

SAS Institute, Inc. 1988. SAS/STAT user's guide, Release 6.03 Edition. SAS Institute Inc. Carv, NC.

Sims, R.A., W.D. Towill, K.A. Baldwin and G.M. Wickware. 1989. Field guide to forest ecosystem classification for Northwestern Ontario. Ont. Min. Nat. Res., Queen's Printer For Ontario, Toronto. van der Kamp, B.J. 1981. The incidence and impact of western gall rust, stalactiform rust and atropellis canker on managed stands of interior lodgepole pine. B.C. Min. For. (submitted).

van der Kamp, B.J. 1988a. Temporal and spatial variation in infection of lodgepole pine by western gall rust. Plant Disease 72: 787-790. van der Kamp, B.J. 1988b. Susceptibility of lodgepole pine provenances to geographically separate western gall rust spore sources. Can. J. For. Res. 18: 1203-1205.

van der Kamp, B.J. and M. Spence. 1987. Stem diseases of lodgepole pine in the British Columbia interior following juvenile spacing. For. Chron. 63: 334-339. 
Wallace, D.R. and C.R. Sullivan. 1985. The white pine weevil, Pissodes strobi (Coleoptera: Curculionidae): a review emphasizing behaviour and development in relation to physical factors. Proc. Entomol. Soc. Ont. Suppl. Vol. 116: 39-62.

White, R.G. and J.M. Waldram. 1991. Overview of thinning in the Northwestern region of Ontario. pp 37-43 In V.F. Haavisto, C.R. Smith and C. Mason (eds.) Space to grow: spacing and thinning in northern Ontario. 1991. Forestry Canada, Ontario Region Joint Report 15. Yanchuk, A.D., F.C. Yeh and B.P. Dancik. 1988. Variation of stem rust resistance in a lodgepole pine provenance-family plantation. Forest Science 34: 1067-1075. 